\title{
Organizational Design for Institutional Change: the case of MPB Festivals, 1960 to $1968^{(1)}$
}

\author{
Charles Kirschbaum* \\ E-mail address: kircharles@fei.edu.br \\ Centro Universitário da FEI \\ São Paulo, SP, Brazil
}

\begin{abstract}
A central concern in neo-institutional research is the genesis of new organizational fields. This article explores the emergence of the MPB (Brazilian Popular Music) field in tandem with the organization of music festivals in the sixties. The festivals were instrumental in combining musicians, critics and the audience in a forum relatively buffered from the music industry influence. This interaction supported the introduction and diffusion of new influences in the popular music field, and at the same time, it consecrated the category MPB as a high-brow art form. The festivals' design provoked two unintended consequences: the conflict between musicians and the audience, and between musicians and the jury. While several musicians strived to conquer autonomy for their creative activity, the audience claimed its supremacy. As a result, musicians exerted pressure on the jury to buffer the aesthetical criteria from the audience. It concludes with a critical appraisal of the role of festivals in the evolution of the MPB field.
\end{abstract}

Key words: neo-institutionalism; organizational fields; organizational theory; sociology of arts; music industry.

Received 21 February 2006; received in revised form 30 May 2006.

Copyright (C) 2006 Brazilian Administration Review. All rights reserved, including rights for translation. Parts of this work may be quoted without prior knowledge on the condition that the source is identified.

\footnotetext{
* Corresponding author: Charles Kirschbaum

Rua Tamandaré, 688, 01525-000, São Paulo, SP, Brazil.
} 


\section{INTRODUCTION}

An organizational field is usually described as a set of actors arrayed in an industry or sector. In this context, these actors engage in mutual monitoring, follow common practices and abide by the field's norms. Such practices, as proposed by early neo-institutionalist studies, are introduced by institutional entrepreneurs (DiMaggio, 1991) and diffused through coercive, normative and mimetic isomorphism (DiMaggio \& Powell, 1983). Not only Neo-Insitutionalists but also other theorists of fields (Bourdieu \& Wacquant, 1992; Fligstein, 2001) have stressed that the enactment of norms and practices do not depend on direct contact among individuals. Despite important research having explored how practices and norms are diffused through interaction, especially through social networks (Burt, 1987, Galaskiewicz \& Wasserman, 1989), Bourdieu considered the interactionist approach problematic, if not irrelevant, for the study of fields.

This article seeks to explore the interactionist dimension of institutional creation and change and, as a consequence, it should be accounted as a major repertoire for explaining how fields are constituted. For that purpose, I revisit the MPB (Brazilian Popular Music) Festivals history in the sixties. Throughout the article, I describe the festivals as a special kind of organization where musicians, jury and the audience were placed together and in direct interaction, allowing those actors to engage in various ways. Following this logic, I claim that the interaction at the Festivals played two important roles when I rebuild the formation of the MPB field. First, they made possible the inclusion of different styles and influences in the phonographic industry. As such, they were a device for channeling innovation into the system. Second, and paradoxically, the Festivals legitimated and consecrated a repertoire that would be eventually labeled as MPB, in contrast with previous movements but also as a category applied to distinguish it from folk and low-brow popular music.

Firstly, I explore some theoretical intersections between the current sociology of art and sociology of organizations, where I place the interaction dimension as an explanatory factor while assessing institutional change. Secondly, I revisit the history of the Festivals and the economic, political and technological background as well. Thirdly, I investigate how the Festivals were structured and why they were important for the institutionalization of the MPB field. Finally, this article discusses some possible paths that attempt to reinforce the interactionist approach to institutional analysis.

\section{The Role Of INTERACTIONS AND CONFLICTS IN EXPLAINING INSTITUTIONAL CHANGE}

The sociology of art has borrowed several theoretical frameworks from organizational studies in order to understand how new practices and norms diffuse among art fields. Conversely, organizational sociologists have explored phenomena in art fields in order to understand complex institutional processes (for a review, see DiMaggio, 2000).

Becker (1974) showed that artistic creativity is more a result of cooperative efforts than an isolated act of an individual genius. According to the production perspective in cultural sociology, social structures as well as culture are seen as elements in an ever changing patchwork. Thus, it is possible to picture the Festivals as a venue for exposing the latest creations in the field, enabling each actor engaged in the competition to search for new breakthroughs or innovations in their music or performance to overcome their opponents in order to get the award, and the corresponding glory.

An important contribution from this cross-fertilization process came from Hirsch (2001), who proposed that current cultural industries may be depicted as open systems. In this account, recording companies have little control on the trends of the music industry: musicians create new styles in loosely coupled networks, and the audience's taste shifts are hardly predictable. As a result, Hirsch 
stressed the importance of boundary-spanning roles in music labels in order to quickly monitor trends in the market. Following Hirsch's lead, DiMaggio (1977) suggested that incumbent organizations in creative industries strive to keep the pace of innovation under control. In other words, incumbent players attempt to create barriers against disruptive innovations due to fads and fashion cycles. For that purpose, organizations in cultural industries rely heavily on taste-formers and brokers, like critics and curators. The delegation of the aesthetic judgment to third-parties plays also an important role in legitimating the aesthetic values, for a market-only valuation robs the art piece its status of exclusivity (DiMaggio, 1982 in reference to the Weberian idea of separation of value spheres). As a result, we end up with an imagery of art fields highly mediated by taste-makers: awards, ratings and rankings are attempts to signal quality, allocation criteria and trends (Anand \& Watson, 2004; Schmutz, 2005).

Mouzelis (1995) argues that a sociological analysis should exhaust three dimensions of a given phenomena: the macro structure where it is embedded, the actors' interests and their respective cognitive schemata and finally the immediate interaction pattern among the actors. Mouzelis argues that although these dimensions are empirically intertwined, analytically they are not reducible to each other. In other words, the explanation of social phenomena reflects aspects of these three dimensions. As we shift our analytical lenses to the immediate interaction among the field's actors, I borrow Goffman's contribution on how a particular interaction order is established (Goffman, 1967; Rawls, 1989). The interaction order mediates the overall social structure and the individuals' action, and regulates the games the individuals play. Although we may understand the interaction order as an institutional aspect that influences the individuals' behavior, it is not necessarily subordinated to the overall institutional structure in a field. In our example of the music festivals, the real-time reaction from the audience could possibly not be aligned with the official critics or the host media's opinion. As a result, the interaction order emerges as a powerful autonomous explanatory concept in the explanation of institutional change in organizational fields.

The games played in direct interactions are embedded in what Durkheim (1915) identified as rituals. Rituals play the important role of synchronizing the individuals' bodies, attention and action in a given setting. Rituals do not always entail cooperation among individuals, but they also provide scripts for conflicts (Collins, 2004). A conflictive ritual engages its participants' emotional energy towards the craved award, trophy or symbolic recognition. As a result, the actors fully engaged in the conflictive game will eventually pursue innovative avenues in order to overcome each other. For instance, Collins (2000) proposed a sociological history of Philosophy by describing the conflicts and games the philosophers played with and against each other. Simmel (1955) and later Coser (1966) proposed that conflicts were not necessarily disruptive in a society. In contrast, conflicts have the role of renewing values and consequently social ties. Abbott (1988) shows how different professional bodies construct patterns of interactions out of conflictive processes. As I suggested above, I believe that the Festivals were privileged organizational forms where direct and conflictive interaction took place. Moreover, the conflictive-ridden aspect of Festivals was an important factor to explain the rapid change in the Brazilian Popular Music in that period.

\section{LABELING: COGNITIVE AND INSTITUTIONAL APPROACHES}

Weick's (1969) seminal work on organizing activity stressed the role of labeling as inherent to organizational life. Danton (1964) affirmed that an object will be accepted as an art piece if and only if members of an Art World recognize it as such. Therefore, the task of categorizing and evaluating is usually performed by critics, curators, producers, and distribution personnel. As DiMaggio (1987) showed, these different roles may arrive to very divergent classificatory systems. Depending on how the art piece is classified, it may achieve very different audiences (Greenfeld, 1989). Moreover, several actors may use strategically the available classification systems in order to exclude new entrants and mavericks from the field (Becker, 1982; Bourdieu, 1993). As such, classificatory systems work as social institutions (Douglas, 1986), grounded on cognitive and normative structures. 
During the Festivals, the actors involved sustained two opposing forces. First, as proposed above, they aimed at a continuous increase in the porosity of the phonographic industry's boundaries. Yet, they struggled to establish the label MPB as an effective institution to help the task of separating lowbrow and high-brow popular music. Collins's (1980) reading on Weber suggests that institutions are the outcome of compromises among conflictive processes. Following Collins, I examine to what extent the establishment of the label MPB was the outcome of a conflicts that took place during the sixties and coalesced in the Festivals.

\section{BRAZIL - LATE 50’s AND 60's: INSTITUTIONAL AND HISTORICAL FACTORS}

The post-war period in Brazil was celebrated with a surge in economic activity. The government of Juscelino Kubitschek advanced the industrial structure in the country, promoting a fast change in Brazilian demography. Brazil was perceived as the "country of the future". Nonetheless, the slowing down of the economic growth led several social actors to clash with each other.

Although João Goulart was led to power in order to fulfill his promise to promote structural reforms (e.g. Agrarian distribution) he failed to contain the polarization among several groups in society. The military coup in 1964 is interpreted by some scholars as the outcome of this stalemate established among opposing parties outside the reach of Congress (Figueiredo, 1993). The explicit objective of the military dictatorship established in 1964 was to return to the democratic regime as soon as possible. This transition would take place only in 1985 . Before that, the military regime became fiercer in its repression. The watershed occurred in 1968, when the Institutional Act 5 suspended the habeas corpus and other civil rights.

Nevertheless, the period that stems from April $1^{\text {st }}, 1964$ to the enactment of the AI-5 in 1968 was marked by ambivalence towards democracy, which enabled all citizens to express their ideas. As a result, left-wing groups still retained the cultural hegemony (Schwarz, 1992).

\section{THE History OF STYLES: From BossA TO MPB}

Bossa Nova: The Bossa Nova style seemed to be the perfect screen play for the Juscelino Kubitscheck administration (Treece, 1997). An appropriation of Jazz elements into samba, the Bossa Nova style portrayed a typical Brazilian sound and yet, it was perceived as sophisticated and appropriate for the ascending middle class in Rio de Janeiro (Perrone, 1989, p. xx).

Bossa Nova songs depicted a sunny life and harmonious and romantic relationships. It is not surprising why Bossa Nova was so successful in the jazz field in the early sixties: it portrayed a paradise lost, a world where social conflicts were far from reality. That was a reality sharply different from the United States' scene in the early sixties: African-American Civil Right Movement threatened the society's order.

Most importantly, however, was the role of Bossa Nova as the creator of a professional ethos among young musicians in Brazil. With Vinicius de Morais, a Brazilian diplomat in the movement, and the inclusion of sophisticated harmonization in the music, the style established itself as high-brow, in comparison to samba (Perrone, 1989, p. xxiv).

Jovem Guarda: By the late fifties, artists like Roberto Carlos had begun to target a new market segment still weakly explored: teenagers. By borrowing elements from mid-fifties American and British rock-'n-roll, the Jovem Guarda group (New Guard) was able to capture an audience that was not satisfied neither with Bossa Nova nor with older styles (Sambas, Waltzes, etc.). The softening of 
the initially more offensive aspects of live rock performance made its acceptance possible for a broader audience, so that the new rock singers achieved the kind of national impact which their bossa nova counterparts never could (Anonymous, 1983). In this sense, they played a crucial role in winning away its middle-class youth audience from a conscious political reflection on the nature of the regime.

National Bossa Nova: As the economic growth stalled, Bossa Nova musicians split in two groups. One group developed their careers outside Brazil. A second group stayed in Brazil and grew selfconscious of its social role (Treece, 1997, p.2).

Students, intellectuals and artists began to ask the following question: how a style mostly influenced by Jazz could be recognized as popular. In 1962, the CPC (Culture Popular Center, linked to the National Student Association, UNE) Manifest is launched. As a result, many artists manifested their commitment to improve the popular conscience on matters of social and economic reality and convert those artists who produced alienated or art-for-art sake to the political conscious group. The ultimate aim was to improve the nation's material condition (Treece, 1997, p. 28). Nara Leão, as Carlos Lyra and other musicians, saw artistry as subordinated to far-reaching political purposes. They could not accept art as art-for-itself. Moreover, it was important to recover the Brazilian folk roots and resist the influence of Jazz. This was the beginning of the National Bossa Nova movement.

The themes in this new phase of popular music ranged from regionalist rhythms to social-conscious songs. The public's acceptance of politically engaged songs led many musicians (even some Jovem Guarda members) to compose protest songs. These songs expressed the dissatisfaction with the current political and social context. Artists in this movement saw other artists as alienated and avoiding their roles of promoters of social change. This movement grew stronger in its political purpose after the coup in 1964, and the stage was seen as an instrument for political expression. In contrast with the first generation of Bossa Nova musicians, these interpreters and composers favored the content of the lyrics rather than the form and harmonic features of their elder counterparts (Perrone, 1989, p. xxvi). In addition, this group aimed at the purification of the Brazilian music from foreign influences. One expression of this radicalization was the street protest against the inclusion of electric guitars in Brazilian popular music. Electric guitars were epitomized as the symbol of American imperialist colonization through rock-‘n-roll, and should be resisted (Calado, 1997).

Tropicalia: Amidst the clash between the radically political-conscious musicians and other musicians, in 1967 the Tropicalia movement emerged as a narrator and of this moment and challenger of this dichotomy. Their songs (especially those of Caetano Veloso) resembled a pastiche of Bossa Nova, protest and Jovem Guarda songs. Moreover, their songs included electric guitars (especially the Mutantes), defying the ban on rock influences. The ethos of this group was to combat the sectarian attitude of protest song musicians. In sharp confrontation, they believed that art-for-its-sake should be defended (Calado, 1997), for the autonomy of creative activity would converge with the pursuit of citizenship and democracy (Veloso, 1997).

Upon its inception, the Tropicalista movement faced strong opposition from politically engaged musicians. At a period when several artists (including theater actors) were already suffering repression due to their political positions, Tropicalistas seemed to be out of synchrony with the historical moment. In contrast to Jovem Guarda's musicians, the Tropicalistas were seen as consciously betraying the political cause. It is worth noting that the Tropicalistas, many of them from Bahia, were introduced to the musical field by strongly engaged musicians like Elis Regina (Calado, 1997). Ironically, by introducing foreign elements into Brazilian music and yet retaining some of the harmonic complexity of BN, the Tropicalistas claimed that they were the true heirs of João Gilberto (Calado, 1997). Eventually many of the elements introduced by the Tropicalistas were absorbed by its detractors.

MPB (Brazilian Popular Music): It is hard to identify who created the label MPB. Solano Ribeiro (2003) claims to be the inventor of this acronym, for he was the organizer of the first MPB Festival in 1965. Historians believe that by the late sixties Nara Leão and her colleagues started to question the label Bossa Nova and proposed MPB as a better name, identified with nationalistic and social causes. 
Currently, the acronym MPB is loosely related to songs and artists who gained fame at the musical Festivals in the sixties (Mello, 2003; Ribeiro, 2003). This consecrated repertoire includes not only the winning songs, but also many songs that didn't receive awards, but were eventually recognized as invaluable for the Brazilian music vernacular. In tandem with the popularization of the MPB category, other labels phased away - they were all included in the same categorical umbrella (Perrone, 1989, p. 202).

To be sure, many songs that are currently believed to be part of the basis of MPB were composed during the seventies, when the Festivals were already unexpressive. However, most of the musicians who lately contributed to the MPB repertoire established their foothold and status in the field during the Festivals in the sixties (Perrone, 1989). Next, I explore the role of Festivals in promoting the emergence of new styles and eventually the consolidation of the MPB label.

\section{Festivals: Origins, Structure, ImPact, DeVelopment, Role}

\section{Origin and Diffusion of the Festivals}

The first popular music Festival was held in 1960 in Guarujá, a beach resort in São Paulo, hosted by Record, one of the most important TV channels at that time (Mello, 2003). But it was not before 1965 that the Festival fever took hold of the country. In 1965, Solano Ribeiro organized a festival based on San Remo's festival. In contrast with the later, Solano proposed a structure that would not be subordinated to the interests of recording companies (Ribeiro, 2003, p. 67). In agreement with DiMaggio's proposition that institutional entrepreneurs match organizational formats with emergent cognitive schemata and values (DiMaggio, 1991), Solano Ribeiro embraced a buffering strategy: "I made the decision that in order to maintain my autonomy and the festival's rightness; I would not permit the participation of any publishing house or recording company.” (Ribeiro, 2003, p. 67).

Nevertheless, Ribeiro and his associates had in mind a different concept in contrast with the Grammy award. Introduced in 1958 in the United States, the Grammy had the intention of awarding those artists who were recognized as important contributors to the music field by musicians themselves. As a result, the Grammy not always confirmed the popular acceptance (Anand \& Watson, 2004; Schmutz, 2005). In contrast, the first MPB Festival tried to construct their criteria retrospectively in order to please the public taste (Ribeiro, 2003, p. 91).

As a result, the festival signaled the audience's taste to the recording companies. In other words, it was able to establish a bottom-up rather than a top-down system of taste formation. The first festival's success led to a diffusion of its format to other TV Stations, universities and other venues that promoted festivals of their own. The most important festivals were held by the young TV stations (Record, Excelsior, Tupi and later Globo).

In contrast with its counterparts in other Latin American countries, these TV stations did not censor left-wing content, in spite of the ongoing dictatorship. Later censorship came only after 1968. Rather than political alignment, TV stations were striving for higher audience rates. As a result, controversies among the musical world were extremely attractive for the TV executives.

\section{Structure}

Festivals were constituted by three important groups: musicians, jury and audience. The jury included music critics, orchestra conductors, journalists and musicians. It was intended to be permanent and represent the field's most important artists and taste-makers (Mello, 2003, p. 189; Ribeiro, 2003, p. 68). 
The Festivals, designed to screen and select the best popular musicians in Brazil, gave to the field's actors an opportunity for direct interaction. The jury was placed next to the stage, where musicians performed their or third-party's songs. In real-time, the audience reacted to the performance with ovation or booing. Although this instant feedback was not supposed to influence the jury's judgment, it certainly established an immediate dialogue among those present. Moreover, the audience's feedback could positively or negatively impact on the musicians' performance. Although the interaction between musicians, public and jury was well received, the interaction between recording companies, journalists, and sponsors with the jury was seen as a threat to the latter's sovereignty (Ribeiro, 2003, p. 70). As a result, the festivals' organizers had to buffer the jury from the external influences, which could lead to literally hiding the former from the latter (Ribeiro, 2003)

\section{Role of Festivals on Style Emergence}

As suggested above, several musicians competing at the Festivals embodied in their lyrics a response to the CPC Manifest's will of enlarging the circuit of recorded popular music. At first that entailed in the recovery of older styles and the introduction of regionalist (i.e., outside the Rio de Janeiro's circuit) styles. In 1965, Elis Regina won the first Excelsior Festival with the song Arrastão, which was strongly influenced by North-Eastern accent. Also, in 1966, Chico Buarque and Nara Leão won the second Festival at Record with the song $A$ Banda, which was a recovery of old-fashioned march songs, yet utopian themes. In 1967, Milton Nascimento, from Minas Gerais, won the second place at the FIC (at Globo), with his song Travessia.

In tandem with the more folk and regionalist trends, politically-conscious songs achieved the jury's recognition. Pra Não Dizer Que Não Falei de Flores by Geraldo Vandré won the second place at the FIC in 1968. This song was strongly supported by the audience. In 1967, the Tropicalistas seemed to conquer their share of spot light. Gilberto Gil won the second place at the Record's Festival with his song Domingo no Parque. That was the beginning of the Tropicalistas' rise.

\section{Interactions and Conflicts}

Audience and Musicians: In the beginning of the Festivals, the audience was divided in groups who supported their favorite singers or composers. Increasingly, musicians embraced a stronger political position and discourse, in parallel to a transformation in the audience, as it became more politically-conscious. Polarization was not anymore based on taste, regional origin or music quality, but on political message contained in the songs (Veloso, 1997, pp. 230-236).

Several events marked conflicts and clashes among critics, musicians and audience. When Vandré gained the second place next to Sabiá (Chico Buarque and Tom Jobim), the audience complained furiously. Still, Vandré asked the audience to respect the jury's sovereignty as the only source of legitimacy (Ribeiro, 2003, p. 118).

But the confrontation escalated to emotional outbursts. Sérgio Ricardo crashed his guitar against the stage, due to the continuous protests from the audience, who wouldn't allow him to sing. Caetano Veloso abandoned the stage, after trying to sing É Proibido Proibir (It is forbidden to forbid). The booing of the audience prevented him from finishing the song.

Musicians and Jury: Although the conflict between Tropicalists and the public is sufficiently documented (Calado, 1997; Ribeiro, 2003; Veloso, 1997; Zuza, 2003), less attention has been devoted to understanding the conflict between the Tropicalists and the jury. Both Ribeiro and Homem de Mello refer to Caetano's É Proibido Proibir as an attempt to provoke the audience. Ribeiro (2003) claims that the musicians' outlandish outfits and the song's atonal features irritated the audience, who in turn overreacted.

Caetano Veloso presents a different perspective: his target was not only the audience, but also the jury. The Tropicalistas (including Caetano Veloso, Gilberto Gil and the Mutantes) were looking 
forward to introduce innovations in the popular music. One of the most important influences was Jimmy Hendrix, who was introducing dissonant chords and atonal songs to Rock. In contrast, the jury did not accept Gil's song. Veloso claims that the jury was not aware of what had been already accepted abroad (Veloso, 1997, p. 302). By the design of the Festival, however, the jury could not go against the audience, and its attempts to favor one song rather another, in spite of the audience's taste, led to furious reactions. As a result, the Tropicalistas' effort was to make explicit the subordination of the jury to the audience, which could lead to a higher discretion to the former.

Among Musicians: the history of the Festivals is also the history of struggles among musicians. While Nationalist Bossa Nova players opposed Jovem Guarda musicians, among the former group sub-groups struggled for space. Nara Leão opposed Elis Regina, etc. Nevertheless, the media fueled many of these fights, for the private and the public lives of artists always make popular news. Caetano Veloso (1997, p.230) refers to his conflict with Chico Buarque as mostly based on musical, perhaps ideological choices, but never on professional respect as the press portrayed.

\section{Censorship and Decline}

In 1968 the dictatorship took a radical shift. Basic civil rights were suspended, the censorship was fiercer and several musicians were led to exile. Ironically, even the art-for-its-sake musicians were invited to leave the country. Although the Festivals were still held, the TV stations, under government direction, exerted direct control on the jury's decision. As a result, the Festivals grew increasingly empty of its original legitimacy. They were no longer a forum for direct confrontation of styles and ideas.

\section{DISCUSSION AND CONCLUSION}

Let us recover the explicit intent of Solano Ribeiro and his associates in 1965: they intended to promote high-quality (one should read high-brow Bossa Nova heritage) music through festivals. This purpose was partially supported by the festival's organizational design. On one hand, they succeeded in buffering the jury from the music industry pressures. However, the jury's decision was somewhat subordinated to the audience's reactions. This design led to some important unintended consequences. First, the audience grew more aggressive, as many musicians resisted their requirements. Second, a growing tension between musicians and jury posed questions on the legitimacy of the latter. Finally, the media transformed the conflict among musicians in ideological struggles, which reinforced the polarization in the audience. At this point, we may ask what would have happen if the censorship did not subdue the festivals. For this rhetorical question, I offer three - not necessarily excluding propositions.

First proposition: the Festivals would become increasingly dominated by recording companies. As Melly (1989) suggests, all sub-culture movements seem to slow down after it achieves its stated goals or at least its general rationale is widely accepted by society. The convergence of the jury's opinion and the recording companies' influence at the Grammy (Schmutz, 2005) corroborates this tendency. The same might had happened with the institutionalization of MPB.

Second proposition: the festivals would help to promote new styles and new entrants. As the recording industry system became more porous in order to absorb musical influences outside Rio de Janeiro, larger audiences started to gain access to unheard styles and accents. This trend led to the absorption of artists, like Milton Nascimento and Gilberto Gil, who were not originally from the Rio de Janeiro-São Paulo axis. This trend might have been even stronger, leading to a wider network of musicians and faster mobility and motility of stars. To be sure, later attempts to introduce foreign elements to MPB, like Funk, Rock or Rap were accepted, but mostly promoted by the MBP stars consecrated during the festivals (Perrone, 1989, p. 203). 
Third proposition: the festivals would become increasingly aligned with the art-for-itself ethos. As art-for-itslef musicians (i.e. Tropicalistas) pushed the festival's structure to buffer the jury from the audience, the former would feel pressed to justify its existence as an autonomous body in relation to the audience. To be sure, the festivals were structures that depended on TV support and sponsorship. As a result, such autonomous art-for-itself festivals would face extraordinary obstacles to find sponsorship. On the other hand, although the Tropicalistas aimed to introduce such novelties to the field, they did not attempt to become isolated from the market. Their perceived "tactic or strategy was to fake adherence to the system (...) and eventually smuggle quality elements" (Veloso, 1997, p. 306). Although this ambivalent strategy (close to a decoupling maneuver; see Meyer and Rowan, 1991) had proved successful, we should suspect that this position would not be sustainable in the long run. Increased tensions could lead to a fragmentation and differentiation among the festivals.

Nowadays musicians, critics and historians look at the festivals in the sixties with nostalgia. They claim that those festivals were able to bring new talents to the overall music industry, while currently the festivals held have very limited reach (Ribeiro, 2003). As a consequence, many attempt to strength the Festivals as a channel for change.

As suggested by the three propositions above, the potential for a perennial change should be checked against other societal forces: (a) increased coupling of festivals to the music industry, (b) routinization of innovation and (c) fragmentation. In contrast, the festivals could be sparsely used a device for social change. As social movement scholars suggest, change might be achieved through the acquisition of accepted and legitimate resources (McAdam \& Scott, 2005). Vibrant festivals were and might become again viable institutional resources for change. Conversely, new distribution channels might support the diffusion of new trends within or outside the MPB art world.

\section{NOTE}

\footnotetext{
${ }^{1}$ I would like to thank Prof. Patrícia da Cunha Tavares for her insights, heated debates and references, which deeply influenced the development of this article.
}

\section{REFERENCES}

Abbott, A. (1988). The System of Professions. In A. Abbott (Ed.), The System of Professions: An Essay on the Division of Expert Labor (pp. 86-113). Chicago: University of Chicago Press.

Anonymous (1983). Jovem Guarda. Vigu Especial, 5(56), 4-15.

Anand, N., \& Watson, M. R. (2004). Tournament rituals in the evolution of fields: The case of the Grammy Awards. Academy of Management Journal 47(1), 59-80.

Becker, H. S. (1974). Art As Collective Action. American Sociological Review, 39(6), 767-776.

Becker, H. S. (1982). Art Worlds. Berkeley, CA: Univerisity of California Press.

Bourdieu, P. (1993). The Production of Belief: contribution to an economy of symbolic goods. In The Field of Cultural Production (pp. 74-111). N.Y.: Columbia Univ. Press.

Bourdieu, P., \& Wacquant, L. J. D. (1992). The Purpose of Reflexive Sociology (The Chicago Workshop). In P. Bourdieu \& L. J. D. Wacquant (Eds.). An Invitation to Reflexive Sociology (pp. 61-215). Chicago: The University of Chicago Press.

Burt, R. S. (1987). Social Contagion and Innovation: Cohesion Versus Structural Equivalence. The American Journal of Sociology, 92(6), 1287-1335. 
Calado, C. (1997). Tropicália: A História de uma Revolução Musical. São Paulo: Editora 34.

Collins, R. (1980). Weber's Last Theory of Capitalism: A Systematization. American Sociological Review, 45(6), 925-942.

Collins, R. (2000). The Sociology of Philosophies: A Précis. Philosophy of the Social Sciences, 30(2), 157-201.

Collins, R. (2004). Interaction Ritual Chains. Princeton, NJ: Princeton University Press.

Coser, L. A. (1966). The functions of social conflict. New York: Free Press.

Danto, A. (1964). The Artworld. The Journal of Philosophy, 61(19), 571-584.

DiMaggio, P. (1977). Market Structure, the Creative Process, and Popular Culture: Toward an Organizational Reinterpretation of Mass-Culture Theory. Journal of Popular Culture, 11(2), 436452.

DiMaggio, P. (1982). Cultural entrepreneurship in nineteenth-century Boston: the creation of an organizational base for high culture in America. Media, Culture and Society, 4, 33-50.

DiMaggio, P. J. (1987). Classification in Art. American Sociological Review, 52(4), 440-455.

DiMaggio, P. J. (1991). Constructing an Organizational Field as a Professional Project: U.S. art museums. In W. W. Powell \& P. J. DiMaggio (Eds.), The New Institutionalism in Organizational Analysis (pp. 267-292). Chicago: The University of Chicago Press.

DiMaggio, P. (2000). The production of scientific change: Richard Peterson and the institutional turn in cultural sociology. Poetics, 28, 107-136

DiMaggio, P. J., \& Powell, W. W. (1983). The Iron Cage Revisited: Institutional Isomorphism and Collective Rationality. American Sociological Review, 48(2), 147-160.

Douglas, M. (1986). How Institutions Think. Syracuse: Syracuse University Press.

Durkheim, E. (1915). The Elementary Forms of the Religious Life. New York: The Free Press.

Figueiredo, A. C. (1993). Democracia ou reformas?. Alternativas democráticas à crise política: 19611964. São Paulo: Paz e Terra.

Fligstein, N. (2001). The Architecture of Markets: an economic sociology of twenty-first-century capitalist societies. Princeton: Princeton University Press.

Galaskiewicz, J., \& Wasserman, S. (1989). Mimetic Processes Within an Interorganizational Field: An Empirical Test Administrative Science Quarterly, 34(3), 454-479.

Goffman, E. (1967). Interaction Ritual: Essays on Face-to-Face Behavior. NY: Pantheon.

Greenfeld, L. (1989). Different Worlds: a sociological study of taste, choice and success in art. Cambridge, UK: Cambridge University Press.

Hirsch, P. M. (2001). Processing Fads and Fashions: an organization-set analysis of cultural industry systems. In M. Granovetter \& R. Swedberg (Eds.), The Sociology of Economic Life (pp. 287-304). Boulder: Westview Press.

McAdam, D., \& Scott, W. R. (2005). Organizations and movements In G. F. Davis, D. McAdam, W. R. Scott \& M. N. Zald (Eds.), Social Movements and Organization Theory (pp. 4-40). New York: Cambridge University Press.

Mello, Z. H. (2003). A era dos Festivais: uma parábola. Sâo Paulo: Editora 34

Melly, G. (1989). Revolt into Style: Pop Arts in the 50s and 60s Oxford: Oxford Paperbacks . 288 p. 
Meyer, J. W., \& Rowan, B. (1991). Institutionalized Organizations: Formal Structure as Myth and Ceremony. In P. J. DiMaggio \& W. W. Powell (Eds.), The New Institutionalism in Organizational Analysis. Chicago: The University of Chicago Press.

Mouzelis, N. (1995). Sociological Theory: What Went Wrong? Diagnosis and Remedies. London: Routledge.

Perrone, C. A. (1989). Masters of Contemporary Brazilian Song: MPB 1965-1985. Austin: University of Texas Press.

Rawls, A. W. (1989). Simmel, Parsons and the Interaction Order. Sociological Theory, 7(1), 124-129.

Ribeiro, S. (2003). Prepare o Seu Coração. São Paulo: Geração Editorial.

Schmutz, V. (2005). Retrospective Cultural Consecration in Popular Music. American Behavioral Scientist, 48(11), 1510-1523.

Schwarz, R. (1992). Culture and politics in Brazil, 1964-1968. In R. Schwarz (Ed.), Misplaced Ideas: Essays on Brazilian Culture. London: Verso

Simmel, G. (1955). Conflict and The Web of Group-Affiliations (K. H. Wolff, Trans.). Glencoe, IL: The Free Press.

Treece, D. (1997). “Guns and roses: bossa nova and Brazil’s music of popular protest, 1958-68”. Popular Music, vol. 16/1.

Weick, K. E. 1969. The Social Psychology of Organizing. Addison-Wesley, Reading, MA.

Veloso, C. (1997). Verdade tropical. São Paulo: Companhia das Letras. 